ISSN 1392-3196 / e-ISSN 2335-8947

Zemdirbyste-Agriculture, vol. 107, No. 1 (2020), p. 87-94

DOI $10.13080 /$ z-a.2020.107.012

\title{
Effect of extrusion on the chemical composition of the faba beans and its influence on lactation performance of dairy cows
}

\author{
Ieva KUDLINSKIENE ${ }^{1}$, Romas GRUŽAUSKAS ${ }^{1}$, Agila DAUKŠIENE ${ }^{1}$, \\ Gintare DOVIDAITIENE ${ }^{1}$, Rasa ŽELVYTE் ${ }^{1}$, Ingrida MONKEVIČIENE ${ }^{1}$, \\ Evaldas ŠLYŽIUS ${ }^{1}$, Danguole URBŠIENE ${ }^{2}$, Asta RACEVIČIŪTĖ-STUPELIENÉ ${ }^{1}$, \\ Meelis OTS $^{3}$, Marko KASS ${ }^{3}$, Henrikas ŽILINSKAS ${ }^{1}$, Rolandas STANKEVIČIUS' ${ }^{1}$ \\ ${ }^{1}$ Lithuanian University of Health Sciences, Veterinary Academy \\ Tilžès 18, Kaunas, Lithuania \\ E-mail: ieva.kudlinskiene@1smuni.lt \\ ${ }^{2}$ Lithuanian University of Health Sciences, Institute of Animal Science \\ R. Žebenkos 12, Baisogala, Lithuania \\ ${ }^{3}$ Estonian University of Life Sciences, Institute of Veterinary Medicine and Animal Science \\ Fr. R. Kreutzwaldi 46, Tartu, Estonia
}

\begin{abstract}
The objective of the experiment was to study the effect of extrusion process on the nutritive value of faba beans and to determine its effect on lactation performance of dairy cows. The faba beans were extruded in a single screw extruder at a temperature of $135-155^{\circ} \mathrm{C}$. Feed samples were analysed for chemical composition, including amino and fatty acid composition (before and after extrusion). To evaluate the effect of field beans on dairy cows' performance and milk composition, a feeding trial using extruded and non-extruded faba beans in the diets was conducted. The extrusion process had a minor effect on the chemical composition of the faba beans; the crude protein and crude fat contents increased, while the neutral detergent fibre fraction and dry matter decreased. Moreover, no significant effect on the n-6:n-3 ratio of fatty acids and the atherogenic and thrombogenic indices in beans was found. The replacement of un-extruded beans with extruded beans in dairy cow diets had no effect on feed intake or milk yield. Administration of extruded faba beans with concentrate mixture had no effect on other milk traits or efficiency parameters either. These findings indicate that extrusion improves the composition of beans, but the effect on lactation performance of dairy cow is marginal.
\end{abstract}

Key words: dairy cow, heat treatment, milk composition, Vicia faba.

\section{Introduction}

The faba bean (Vicia faba L.) is a legume seed well adapted to most climatic areas of Europe and North America, and it is widely used for animal feed. As other legume crops, faba beans benefit soil fertility by fixing nitrogen and improve soil properties as a catch crop (Kudlinskiene et al., 2018). Faba beans are a rich source of crude protein (260-300 $\left.\mathrm{g} \mathrm{kg}^{-1} \mathrm{DM}\right)$ and starch (400-480 g $\mathrm{kg}^{-1} \mathrm{DM}$ ), depending on the cultivar of the bean (Makkar et al., 1997; Goelema et al., 1999). Moreover, faba beans have a relatively high content of lysine and a relative low amount of methionine (Makkar et al., 1997), making them an attractive supplement for dairy cow diets.

The diet of high-yielding dairy cows should contain ruminally undegradable protein, which supplies an animal with sufficient amounts of essential amino acids. Thermal treatment of protein feeds is common in feed manufacturing to increase the amount of rumen by-pass protein in order to meet protein needs for milk production (Aguilera et al., 1992). Legumes such as faba beans could be a good alternative for common protein supplements in dairy cow nutrition.

Previous studies have assessed the effect of replacing protein feeds such as rapeseed (Puhakka et al., 2016; Ramin et al., 2017) or soybean meal (Tufarelli et al., 2012; Cherif et al., 2018) with faba beans in dairy cow diets. Those studies indicate that the faba bean could be an alternative to other protein feeds without adverse effects on intake or milk yield of the dairy cow. An in vitro study by Vaga et al. (2017) demonstrated that optimum heat treatment is an effective way to increase the content of utilisable crude protein in legumes. Replacing soybean meal with extruded or expanded pea in cow diets had no negative effect on milk yield or composition (Masoero et al., 2006). Moreover, a previous study has demonstrated that supplementation of dairy cows' diets with extruded beans had no adverse effect on milk taste or sensory parameters (Kudlinskienè et al., 2018).

Please use the following format when citing the article:

Kudlinskienė I., Gružauskas R., Daukšienè A., Dovidaitienė G., Želvytė R., Monkevičienė I., Šlyžius E., Urbšienė D., RacevičiūtėStupelienė A., Ots M., Kass M., Žilinskas H., Stankevičius R. 2020. Effect of extrusion on the chemical composition of the faba beans and its influence on lactation performance of dairy cows. Zemdirbyste-Agriculture, 107 (1): 87-94. DOI 10.13080/z-a.2020.107.0012 
Faba beans contain numerous anti-nutritional factors, such as phytic acid, tannins and protease inhibitors, reducing the digestibility of seeds or leading to some pathological conditions (Multari et al., 2015). Therefore, technological processing methods such as extrusion with high pressure, heat and/or steam is used to minimize the negative effects of anti-nutritional factors in legumes. For example, the extrusion of faba beans decreased the concentrations of trypsin inhibitor, phytic $P$ and resistant starch (Chrenkova et al., 2017).

As extrusion process is driven by several factors such as temperature, time of exposure or humidity level, it potentially affects the chemical composition and nutritional value of the faba bean. Goelema et al. (1998) demonstrated that extrusion of field beans reduces protein degradability in the rumen and increases starch digestibility. Therefore, it was hypothesised that the extrusion process has a beneficial effect on nutrient (amino acid profile, fatty acid profile) availability of treated faba beans and may have an impact on the lactation performance of dairy cows.

The objective of the experiment was to study the effect of extrusion process on the nutritive value of faba beans and on lactation performance of dairy cows.

\section{Materials and methods}

Sample characteristics and treatment. Organically cultivated faba bean (Vicia faba L.) plants of cultivar 'Fuego' were collected from organic farm JSC AUGA Grūduva (Lithuania). The annual yield was $3.5 \mathrm{tha}^{-1}$ during a 122-day vegetation period. The mean plant height was $135 \mathrm{~cm}$ and the mean 1000 grain weight was $498.3 \mathrm{~g}$. During the experimental year (2016), the average temperature ranged from $+13.6^{\circ} \mathrm{C}$ at tillering to $+16.1^{\circ} \mathrm{C}$ at the waxy maturity stage of the beans. Precipitation was between 6 and $175 \mathrm{~mm}$ (http://www.meteo.lt/) during different development stages of the legumes.

Faba beans were treated industrially in a single screw extruder Bronto E-100 (Vertical Ltd., Ukraine). The process was conducted without preconditioning, at an internal temperature of $135-155^{\circ} \mathrm{C}$ and head pressure of 30-40 atm. The raw feed material passed the screw barrel while the heat was progressively increased. Post treatment of the feed material consisted of a cooling phase in the cooling drum, with a cold air supply and hot air extraction. Humidity of the feed material was $19-20 \%$ before and $11-10 \%$ after extrusion. After extrusion and cooling the treated beans were mixed into a concentrate mixture and packed in big bags until feeding.

Animals and experimental design. The study was conducted complying with the Law of the Republic of Lithuania on Animal Care, Housing and Use, No. XI2271 as well as complying with the amended order of the State Food and Veterinary Service "On Approval for Requirements for Housing, Care and Use of Animals for Experimental and Other Scientific Research", No. B1872 of 24-09-2015 (TAR, 2015).

Twenty-four Lithuanian Black-and-White multiparous dairy cows were selected (mean $30 \pm 6$ days in milk, $590 \pm 20 \mathrm{~kg}^{-1}$ of body weight) for the feeding trial. The cows, which were in mid-lactation, were divided into two groups (control and experimental), 12 animals in each. The trial lasted for 104 days; an adaptation period of 14 days and 90 days of data collection. The data collection period was divided into three thirty-day periods. The animals were fed a basal diet with grass (first cut, $35.2 \% \mathrm{DM})$ and maize silage $(40.5 \% \mathrm{DM})$, maize grits, straw and concentrate mixture with either untreated or extruded faba beans (Tables 1 and 2).
Table 1. Ingredients and chemical composition of concentrate mixtures

\begin{tabular}{|c|c|c|}
\hline \multirow{2}{*}{ Ingredients } & \multicolumn{2}{|c|}{ Group $\mathrm{g} \mathrm{kg}^{-1}$} \\
\hline & control & experimental \\
\hline Triticale & 237.0 & 237.0 \\
\hline Untreated faba beans & 167.9 & \\
\hline Extruded faba beans & & 167.9 \\
\hline Peas & 167.9 & 167.9 \\
\hline Wheat & 143.1 & 143.1 \\
\hline Extruded soybean & 136.3 & 136.3 \\
\hline Oats & 98.8 & 98.8 \\
\hline Vitamin and mineral supplement & 27.8 & 27.8 \\
\hline Organic acid mixture & 9.90 & 9.90 \\
\hline Sodium dicarbonate $(\mathrm{NaOH})$ & 8.80 & 8.80 \\
\hline Toxin binder & 1.50 & 1.50 \\
\hline Fodder yeast & 1.0 & 1.0 \\
\hline \multicolumn{3}{|c|}{ Chemical composition, in dry matter } \\
\hline Net energy for lactation $\left(\mathrm{NE}_{\mathrm{J}}\right) \mathrm{MJ}$ & 7.27 & 7.28 \\
\hline Sugar $\mathrm{g} \mathrm{kg}^{-1}$ & 67.0 & 69.0 \\
\hline Starch $\mathrm{g} \mathrm{kg}^{-1}$ & 476 & 470 \\
\hline Crude fat $\mathrm{g} \mathrm{kg}^{-1}$ & 47.0 & 47.1 \\
\hline Crude protein $\mathrm{g} \mathrm{kg}^{-1}$ & 205 & 209 \\
\hline Crude fibre $\mathrm{g} \mathrm{kg}^{-1}$ & 36.0 & 36.0 \\
\hline Calcium (Ca) $\mathrm{g} \mathrm{kg}^{-1}$ & 9.68 & 9.68 \\
\hline Phosphorus (P) $\mathrm{g} \mathrm{kg}^{-1}$ & 6.59 & 6.59 \\
\hline Magnesium (Mg) $\mathrm{g} \mathrm{kg}^{-1}$ & 5.34 & 5.34 \\
\hline Natrium (Na) $\mathrm{g} \mathrm{kg}^{-1}$ & 5.38 & 5.38 \\
\hline
\end{tabular}

Table 2. Ingredients and chemical composition of experimental diets

\begin{tabular}{|c|c|c|}
\hline \multirow{2}{*}{ Ingredients } & \multicolumn{2}{|c|}{ Diet, kg per day } \\
\hline & control & experimental \\
\hline $\begin{array}{l}\text { Perennial grass silage } \\
\text { Peg }\end{array}$ & 16.79 & 16.79 \\
\hline Compound feed with untreated faba beans & 9.0 & - \\
\hline Compound feed with extruded faba beans & - & 9.0 \\
\hline Maize grits & 1.50 & 1.50 \\
\hline Salt & 0.05 & 0.05 \\
\hline Maize silage & 16.0 & 16.0 \\
\hline Molasses & 0.25 & 0.25 \\
\hline Barley straw & 1.0 & 1.0 \\
\hline \multicolumn{3}{|c|}{ Chemical composition $\mathrm{g} \mathrm{kg}^{-1} \mathrm{DM}$} \\
\hline Sugar & 33.0 & 33.0 \\
\hline Starch & 277 & 277 \\
\hline Crude fat & 36.0 & 36.0 \\
\hline Crude protein & 162 & 162 \\
\hline Crude fibre & 131 & 131 \\
\hline Calcium (Ca) & 6.40 & 6.40 \\
\hline Phosphorus (P) & 4.31 & 4.31 \\
\hline Magnesium $(\mathrm{Mg})$ & 2.66 & 2.66 \\
\hline Natrium $(\mathrm{Na})$ & 3.24 & 3.24 \\
\hline Net energy for lactation $\left(\mathrm{NE}_{\mathrm{L}}\right) \mathrm{MJ}$ & 6.79 & 6.79 \\
\hline
\end{tabular}

Animals were fed isonitrogenous and isoenergetic in a total mixed ration (Table 2) twice a day on an libitum basis. Cows had continuous access to fresh water during feeding trial.

Sample collection, measurements and analysis. Dry matter intake (DMI) was calculated based on the dry matter (DM) weight of total mixed ration offered and feed orts. Samples of all diet ingredients were taken and analysed in accordance with European Commission Regulation No. 691/2013 amending Regulation (EC) No. $152 / 2009$.

The analyses were carried out at the Analytical Laboratory of the Institute of Animal Science, Lithuanian University of Health Sciences. Collected feed samples, three subsamples of each batch for chemical analyses, were dried at $60^{\circ} \mathrm{C}$ for 20 hours and ground in an ultracentrifugal mill ZM 100 (Retsch GmbH, Germany) with a $1.0 \mathrm{~mm}$ sieve. Crude protein (CP) content was determined by the Kjeldahl method, and conversion factors of 5.7 for wheat, 5.71 for soybean and for other ingredients 6.25 were used to convert total nitrogen to crude protein. Crude fat was extracted with petroleum ether (boiling range of $40-60^{\circ} \mathrm{C}$ ) by the Soxhlet extraction method, continuously for 4 hours. Crude ash was determined by incineration in a muffle furnace at 
$550^{\circ} \mathrm{C}$ for 3 hours (Commission regulation, 2013). Crude fibre was determined as the residue after sequential treatment with hot sulfuric acid $\left(\mathrm{H}_{2} \mathrm{SO}_{4}\right) 1.25 \%$ and hot sodium hydroxide $(\mathrm{NaOH}) 1.25 \%$ according to the Weende method with a Fibertec 2023 FiberCap system (Foss Tecator AB, Sweden). The samples were subjected to fibre component analyses with an ANKOM 220 Fiber Analyzer (ANKOM Technology, USA): acid detergent fibre (ADF) and neutral detergent fibre (NDF) and acid detergent lignin (ADL) using a cell wall detergent fractionation method according to Faithfull (2002). Nitrogen-free extracts (NFE) were calculated as follows: NFE $(\%)=100-($ moisture $\%+$ crude protein $\%$ + crude fat $\%+$ crude ash $\%+$ crude fibre $\%$ ).

Calcium $(\mathrm{Ca})$ and magnesium $(\mathrm{Mg})$ were determined by the atomic absorption spectrometric method, phosphorus (P) and natrium $(\mathrm{N})$ - by the photometric method (AOAC, 2000). Starch content was determined by the Ewers polarimetric method (ISO 10520:1997. Native starch - Determination of starch content - was determined by the Ewers polarimetric method (LST EN ISO 10520:2000)). Sugar was determined by Luff-Schoorl's method.

Feeding software HYBRIMIN® Futter, version 2008 (Hybrimin GmbH \& Co. KG, Germany) was used to calculate energy and nutritional value of the diets. The energy value of the feeds (expressed as net energy for lactation $\left(\mathrm{NE}_{\mathrm{L}}\right)$ was calculated according to Jeroch et al. (1999).

Cows were milked twice a day, and milk yields were recorded by monthly control milking on three consecutive days. Milk samples were analysed for milk fat, milk protein, lactose and urea concentrations. Analysis was carried out with an SE "Pieno tyrimai" (Lituania), using spectrophotometers LactoScope 550 and LactoScope FTIR (Delta Instruments, The Netherlands). Before analysis raw milk samples were pasteurised at a temperature of $74 \pm 2^{\circ} \mathrm{C}$, and then cooled to a temperature of $16 \pm 2^{\circ} \mathrm{C}$. Then the samples (approximately $20 \mathrm{~mL}$ ) were presented to the panel in $30 \mathrm{~mL}$ plastic cups, coded with three digital numbers (Kudlinskienè et al., 2018).

Energy corrected milk (ECM) was calculated based on milk composition as follows:

$\mathrm{ECM}=$ milk yield $(\mathrm{kg}) \times(383 \times$ fat $\%+242 \times$ protein $\%+165.4 \times$ lactose $\%+20.7) / 3140$.

Feed efficiencies of individual cows were calculated based on milk yield (kg per day) and feed intake (kg per day) parameters. Feed conversion ratios were calculated based on feed intake (kg per day) and milk yield ( $\mathrm{kg}$ per day).

Analyses of amino acids of milk and feed samples were performed by the AccQ-Tag method manual (Waters Corp., USA). For these analyses a Shimadzu low pressure gradient HPLC system (Shimadzu Corp., Japan) consisting of solvent delivery module LC-10AT $\mathrm{VP}_{\mathrm{VP}}$, auto injector SIL-10AD $\mathrm{AP}_{\mathrm{VP}}$ column oven CTO-10AC $\mathrm{VP}_{\mathrm{VP}}$, spectrofluorometric detector RF$10 \mathrm{~A}_{\mathrm{XL}}$, system controller SCL-10A $\mathrm{AP}$, on-line degasser DGU-14A, and for HPLC system control and data collection Workstation LC Solution (Shimadzu Corp.) was used. Chromatographic separation by reversedphase HPLC was carried out with a chemistry package Waters AccQ-Tag NovaPak C18 (Waters Corp.), $4 \mu \mathrm{m}$, $150 \times 3.9 \mathrm{~mm}$ chromatography column at a temperature of $37^{\circ} \mathrm{C}$. Separated derivatives were detected at Ex 250 $\mathrm{nm}, \mathrm{Em} 395 \mathrm{~nm}$. A gradient flow was used for separation of amino acid derivatives. The flow rate was set at $1.0 \mathrm{~mL}$ $\min ^{-1}$. The mobile phase consisted of eluent A (prepared from Waters AccQ Tag Eluent A concentrate by diluting of $100 \mathrm{~mL}$ of concentrate to $1 \mathrm{~L}$ of ultrapure water), eluent B (acetonitrile) and eluent C (ultrapure water).
Fatty acid profiles of milk and feed samples were determined with a gas chromatograph GC-2010 (Shimadzu Corp.) with a hydrogen flame detector after extraction by the Folch et al. (1957) method and methylation following the procedure described by Christopherson and Glass (1969). The atherogenicity (AI) and thrombogenicity (TI) indices were calculated as follows:

$\mathrm{AI}=[\mathrm{C} 12: 0+(4 \times \mathrm{C} 14: 0)+\mathrm{C} 16: 0] /[\mathrm{n}-6$ polyunsaturated fatty acids (PUFA) $+\mathrm{n}-3$ polyunsaturated fatty acids (PUFA) + monounsaturated fatty acids (MUFA)]; $\mathrm{TI}=[\mathrm{C} 14: 0+\mathrm{C} 16: 0+\mathrm{C} 18: 0] /[(0.5 \times$ monounsaturated fatty acids (MUFA) $+(0.5 \times$ n-6 polyunsaturated fatty acids (PUFA) $+(3 \times$ n-3 polyunsaturated fatty acids (PUFA) + n-3:n-6 polyunsaturated fatty acids (PUFA)].

Statistical analysis. The software SPSS, version 15.0 (IBM Corp., USA) was used for the statistical analysis of the data. To determine the differences among the means of feed characteristics, the Student's $t$-test was used. To analyse intake and milk performance data, a two-way repeated analysis of variance considering effects of group, time and group by time interaction, and random effect of cow, software $S A S$, version $9.4 \mathrm{~m} 4$ (SAS Institute, USA) was used. The differences were considered statistically significant when $P<0.05$, otherwise declared as not significant.

\section{Results and discussion}

Chemical composition and nutritional value of faba beans. Extrusion may affect the nature of seed components by changing its physical (e.g., particle size), chemical (e.g., starch gelatinization, inactivation of anti-nutrient factors) and nutritional (e.g., nutrient digestibility) properties (Diaz et al., 2006). In this study, the extrusion process had a minor effect on the nutritional and chemical composition as well as energy value of faba beans (Table 3). Treatment with high temperature decreased the NDF fraction, dry matter and nitrogenfree extracts, but increased crude protein and crude fat contents of faba beans.

Table 3. Chemical composition and nutritional value of untreated and extruded faba beans

\begin{tabular}{lccc}
\hline \multicolumn{1}{c}{ Nutrients } & Untreated & Extruded & $P$-value \\
\hline Dry matter g kg-1 & $940.1 \pm 4.9^{*}$ & $909.8 \pm 3.1$ & $\mathrm{~ns}$ \\
\hline \multicolumn{4}{c}{$\mathrm{g} \mathrm{kg}^{-1} \mathrm{DM}$} \\
Crude protein & $232.3 \pm 2.0$ & $272.0 \pm 3.1$ & $\mathrm{~ns}$ \\
Crude fat & $9.9 \pm 0.5$ & $10.1 \pm 0.4$ & $\mathrm{~ns}$ \\
Crude ash & $28.8 \pm 1.4$ & $29.7 \pm 0.8$ & $\mathrm{~ns}$ \\
Nitrogen-free extracts & $563.9 \pm 14.4$ & $533.8 \pm 13.9$ & $\mathrm{~ns}$ \\
Crude fibre & $69.2 \pm 2.8$ & $62.2 \pm 3.2$ & $\mathrm{~ns}$ \\
Acid detergent lignin (ADL) & $8.7 \pm 0.7$ & $7.3 \pm 0.7$ & $\mathrm{~ns}$ \\
Acid detergent fibre (ADF) & $97.1 \pm 0.2$ & $97.7 \pm 6.4$ & $\mathrm{~ns}$ \\
Neutral detergent fibre (NDF) & $168.9 \pm 2.1$ & $91.0 \pm 1.4$ & $P<0.05$ \\
Calcium & $1.09 \pm 0.07$ & $1.24 \pm 0.09$ & $\mathrm{~ns}$ \\
Phosphorus & $4.03 \pm 0.23$ & $4.29 \pm 0.21$ & $\mathrm{~ns}$ \\
Metabolic energy MJ & $12.36 \pm 0.12$ & $12.13 \pm 0.17$ & $\mathrm{~ns}$ \\
Net energy for lactation & $7.76 \pm 0.07$ & $7.61 \pm 0.04$ & $\mathrm{~ns}$ \\
(NE $\mathrm{L}$ ) MJ & & &
\end{tabular}

* - average value \pm standard deviation, ns - not significant

These findings are in line with those reported by Arija et al. (2006) using raw and extruded kidney beans. Also, Goelema et al. (1999) detected an increase in crude protein content with physical treatment such as expanding or pelleting. However, a further study showed that extrusion decreased the amount of crude protein, but the differences between extruded and untreated beans were insignificant (Strauta, Muizniece-Brasava, 
2016). Similar results have been found in with rapeseed, where short-term treatment had no effect on chemical composition (Vadi et al., 2003). Huhtanen et al. (2011) showed that heat treatment causes a decline of crude protein degradability of protein feeds, but this would not increase the protein supply to small intestine.

The lower energy content of extruded faba beans in the present study might be related to the decreased content of nitrogen-free extracts (Table 3 ). Therefore, during extrusion the seeds may undergo reactions, which could be not beneficial (e.g., over-heating) if nutrient availability is detrimental or altered to become resistant to digestion. On the other hand, extrusion had tendency to increase contents of phosphorus and calcium in faba beans, which agrees with the results obtained by Hejdysz et al. (2015). This could be explained by changes occurring during extrusion, as some molecules of inositol hexaphosphate were hydrolysed to penta-, tetra- and triphosphates.

Lower amounts of crude fibre in extruded faba beans were detected, which is in agreement with a tendency reported by Kushwah et al. (2002). Moreover, there was an effect of treatment on the NDF content of extruded faba beans. While detected a lower NDF content for extruded beans, it was still higher compared to soybean meal and grains (NRC, 2001). Contrary to our results, Vaga et al. (2017) found that high temperature and longer treatment period compared to our study increase the concentration of NDF in beans. In addition to that, Micek et al. (2015) showed that NDF and crude protein content of faba bean is largely related to the cultivar.

The study showed no changes in the profile of amino acids of the treated faba beans, except for the amounts of lysine and histidine (Table 4).

In this study, extrusion decreased the amount of lysine of treated beans. Björck and Asp (1983)
Table 4. Contents of amino acids in the untreated and extruded beans $\left(\mathrm{g} \mathrm{kg}^{-1} \mathrm{DM}\right)$

\begin{tabular}{lccc}
\hline \multicolumn{1}{c}{ Amino acids } & Untreated & Extruded & $P$-value \\
\hline & \multicolumn{2}{c}{ Essential amino acids } & \\
\hline Arginine & $28.1 \pm 0.3 *^{*}$ & $28.2 \pm 0.16$ & $\mathrm{~ns}$ \\
Histidine & $12.3 \pm 0.49$ & $9.8 \pm 0.12$ & $P<0.05$ \\
Isoleucine & $11.4 \pm 0.01$ & $11.3 \pm 0.62$ & $\mathrm{~ns}$ \\
Leucine & $19.6 \pm 0.12$ & $19.9 \pm 0.62$ & $\mathrm{~ns}$ \\
Lysine & $16.1 \pm 0.51$ & $15.1 \pm 0.91$ & $P<0.05$ \\
Methionine & $3.8 \pm 0.32$ & $3.7 \pm 0.21$ & $\mathrm{~ns}$ \\
Phenylalanine & $11.1 \pm 0.39$ & $11.5 \pm 0.45$ & $\mathrm{~ns}$ \\
Threonine & $9.9 \pm 0.12$ & $9.6 \pm 0.12$ & $\mathrm{~ns}$ \\
Valine & $11.9 \pm 0.19$ & $11.9 \pm 0.12$ & $\mathrm{~ns}$ \\
\hline & Non-essential amino acids & \\
\hline Alanine & $11.3 \pm 0.16$ & $11.1 \pm 0.55$ & $\mathrm{~ns}$ \\
Aspartic acid & $30.8 \pm 0.31$ & $28.7 \pm 0.39$ & $\mathrm{~ns}$ \\
Glutamic acid & $51.6 \pm 1.02$ & $51.7 \pm 0.21$ & $\mathrm{~ns}$ \\
Glycine & $12.6 \pm 0.31$ & $11.7 \pm 0.51$ & $\mathrm{~ns}$ \\
Proline & $11.6 \pm 0.94$ & $12.7 \pm 0.46$ & $\mathrm{~ns}$ \\
Serine & $13.3 \pm 0.32$ & $13.2 \pm 0.41$ & $\mathrm{~ns}$ \\
Tyrosine & $7.1 \pm 0.19$ & $7.6 \pm 0.91$ & $\mathrm{~ns}$ \\
\hline
\end{tabular}

* - average value \pm standard deviation, ns - not significant

reported that an increase of extruder temperature, screw compression ratio and screw speed led to an increase of lysine degradation. Moreover, Focant et al. (1990) found that the extrusion of pea is associated with higher flow of amino acids into the duodenum. In the present study, a lower amount of histidine was found in the treated beans. This could partly explain the decline in milk protein of treatment cows in the last period of trial. A previous study by Vanhatalo et al. (1999) reported that histidine is the first-limiting amino acid for milk protein synthesis in dairy cows fed grass silage-based diets.

The major fatty acids of studied beans were linoleic acid, oleic acid, palmitic acid and stearic acid, comprising $92.25 \%$ of the total fatty acids content (Table 5).

Table 5. Profile of fatty acids of untreated and extruded faba beans ( $\%$ of total fatty acids)

\begin{tabular}{|c|c|c|c|}
\hline Fatty acids & Untreated & Extruded & $P$-value \\
\hline Lauric acid (C12:0) & $0.04 \pm 0.01 *$ & $0.07 \pm 0.01$ & ns \\
\hline Myristic acid (C14:0) & $0.43 \pm 0.02$ & $0.33 \pm 0.04$ & ns \\
\hline Pentadecanoic acid (C15:0) & $0.19 \pm 0.01$ & $0.14 \pm 0.02$ & ns \\
\hline Palmitic acid (C16:0) & $14.18 \pm 0.51$ & $13.50 \pm 0.21$ & ns \\
\hline Palmitoleic acid (C16:1n-9) & $0.02 \pm 0.01$ & $0.07 \pm 0.01$ & ns \\
\hline Hexadecanoic acid (C16:1n-7) & $0.08 \pm 0.01$ & $0.22 \pm 0.02$ & ns \\
\hline Margaric acid (C17:0) & $0.14 \pm 0.01$ & $0.14 \pm 0.05$ & ns \\
\hline Margaroleic acid (C17:1) & $0.03 \pm 0.02$ & $0.03 \pm 0.01$ & ns \\
\hline Stearic acid (C18:0) & $2.62 \pm 0.09$ & $3.08 \pm 0.12$ & ns \\
\hline Oleic acid (C18:1n-9) & $24.64 \pm 1.00$ & $24.68 \pm 1.01$ & ns \\
\hline Vaccenic acid (C18:1n-7) & $1.08 \pm 0.09$ & $1.18 \pm 0.09$ & ns \\
\hline Linolelaidic acid (trans-C18:2n-6) & $0.04 \pm 0.01$ & $0.05 \pm 0.01$ & ns \\
\hline Linoleic acid (C18:2n-6) & $50.81 \pm 5.02$ & $50.13 \pm 1.59$ & ns \\
\hline$\alpha$-Linoleic acid (C18:3n-3) & $3.48 \pm 0.08$ & $4.26 \pm 0.25$ & ns \\
\hline Arachidic acid (C20:0) & $1.01 \pm 0.02$ & $0.81 \pm 0.05$ & ns \\
\hline Eicosenoic acid (C20:1n-9) & $0.49 \pm 0.03$ & $0.40 \pm 0.06$ & ns \\
\hline Eicosadienoic acid (C20:2n-6) & $0.09 \pm 0.05$ & $0.09 \pm 0.01$ & ns \\
\hline Eicosatrienoic acid (C20:3n-3) & $0.07 \pm 0.01$ & $0.06 \pm 0.01$ & ns \\
\hline Eicosapentaenoic acid (C20:5n-3) & $0.02 \pm 0.01$ & $0.06 \pm 0.01$ & ns \\
\hline Behenic acid (C22:0) & $0.33 \pm 0.03$ & $0.40 \pm 0.09$ & ns \\
\hline Lignoceric acid (C24:0) & $0.16 \pm 0.01$ & $0.18 \pm 0.02$ & ns \\
\hline Nervonic acid (C24:1n-9) & $0.02 \pm 0.01$ & $0.07 \pm 0.01$ & ns \\
\hline Docosapentaenoic acid C22:5n-3 & $0.02 \pm 0.01$ & $0.02 \pm 0.01$ & ns \\
\hline Sum of saturated fatty acids (SFA) & $19.11 \pm 0.12$ & $18.65 \pm 0.23$ & ns \\
\hline The sum of monounsaturated fatty acids (MUFA) & $26.36 \pm 0.51$ & $26.68 \pm 0.99$ & ns \\
\hline The sum of polyunsaturated fatty acids (PUFA) & $54.54 \pm 5.31$ & $54.67 \pm 4.36$ & ns \\
\hline Sum of trans-isomers of acids & $0.04 \pm 0.02$ & $0.05 \pm 0.06$ & ns \\
\hline The PUFA and SFA quantity ratio & 2.85 & 2.93 & ns \\
\hline Sum of n-3 fatty acids & 3.59 & 4.40 & ns \\
\hline Sum of n- 6 fatty acids & 50.94 & 50.27 & ns \\
\hline The $n-6: n-3$ ratio & 14.18 & 11.43 & ns \\
\hline Atherogenicity index & 0.20 & 0.18 & ns \\
\hline Thrombogenicity index & 0.35 & 0.33 & ns \\
\hline Hypocholesterolaemia / hypercholesterolaemia index & 5.48 & 5.81 & ns \\
\hline
\end{tabular}

\footnotetext{
* - average value \pm standard deviation, ns - not significant
} 
Similar results were reported by Grela and Günter (1995) and Mutasim et al. (2017). The extruded faba beans had numerically lower levels of palmitic acid $(\mathrm{C} 16: 0)$ and this led to a decrease in total saturated fatty acids in extruded beans when compared with nonextruded beans (Table 5). The content of total n-3 fatty acids was numerically higher in extruded beans. This is probably associated with an increase of n-3 fatty acids, such as eicosapentaenoic acid (C20:5n-3) and $\alpha$-linoleic acid (C18:3n-3).

There was found no significant effect of extrusion on the n-6:n-3 ratio in extruded beans compared with untreated beans. The $n-6: n-3$ ratio is commonly used as a criterion to describe the nutritional value of fat (Laudadio et al., 2011). In addition, the process of extrusion did not have effect on the atherogenic and thrombogenic indices of the studied feed materials. This is probably related to too short heat treatment time.

Dairy cow feeding trial. In the current study, extrusion of faba beans affected neither dry matter intake (results not shown) nor milk yield (Table 6), these findings are in agreement with the results reported by Ramin et al. (2017). No effect on lactation performance in the study could be also related to relatively small amount of faba beans in the diet compared to other studies. However, Tufarelli et al. (2012) fed treated beans at $34.5 \%$ of concentrate dry matter to cows at the beginning of lactation and found no effect on either dry matter intake or milk yield. This allows the assumption that even untreated faba beans could be fed to dairy cows without any detrimental

Table 6. Effects of dietary treatments on milk yield and milk composition

\begin{tabular}{|c|c|c|c|c|c|c|c|c|}
\hline \multirow{2}{*}{ Traits } & \multirow{2}{*}{ Period } & \multirow{2}{*}{ Control } & \multirow{2}{*}{ Experimental } & \multirow{2}{*}{ RMSE } & \multirow{2}{*}{$P$-value } & \multicolumn{3}{|c|}{$P$-value } \\
\hline & & & & & & treatment & time & $\mathrm{T} \times \mathrm{T}$ \\
\hline \multicolumn{9}{|c|}{ Yield kg } \\
\hline \multirow{4}{*}{ Milk } & day 0 & 35.1 & 34.0 & \multirow{4}{*}{3.73} & 0.58 & \multirow{4}{*}{0.506} & \multirow{4}{*}{$<0.001$} & \multirow{4}{*}{0.355} \\
\hline & day 30 & 31.8 & 33.9 & & 0.25 & & & \\
\hline & day 60 & 28.9 & 31.2 & & 0.23 & & & \\
\hline & day 90 & 28.6 & 28.8 & & 0.94 & & & \\
\hline \multirow{4}{*}{ Fat } & day 0 & 1.37 & 1.34 & \multirow{4}{*}{0.212} & 0.81 & \multirow{4}{*}{0.261} & \multirow{4}{*}{0.055} & \multirow{4}{*}{0.633} \\
\hline & day 30 & 1.37 & 1.49 & & 0.21 & & & \\
\hline & day 60 & 1.20 & 1.32 & & 0.24 & & & \\
\hline & day 90 & 1.37 & 1.42 & & 0.65 & & & \\
\hline \multirow{4}{*}{ Protein } & day 0 & 1.11 & 1.09 & \multirow{4}{*}{0.156} & 0.86 & \multirow{4}{*}{0.259} & \multirow{4}{*}{0.039} & \multirow{4}{*}{0.605} \\
\hline & day 30 & 1.00 & 1.02 & & 0.73 & & & \\
\hline & day 60 & 0.93 & 1.02 & & 0.24 & & & \\
\hline & day 90 & 0.94 & 1.04 & & 0.17 & & & \\
\hline \multirow{4}{*}{ Lactose } & day 0 & 1.63 & 1.56 & \multirow{4}{*}{0.178} & 0.46 & \multirow{4}{*}{0.577} & \multirow{4}{*}{$<0.0001$} & \\
\hline & day 30 & 1.49 & 1.58 & & 0.32 & & & \\
\hline & day 60 & 1.35 & 1.45 & & 0.25 & & & 0.344 \\
\hline & day 90 & 1.32 & 1.34 & & 0.89 & & & \\
\hline & & & Con & atration ${ }^{0}$ & & & & \\
\hline & day 0 & 3.90 & 3.95 & & 0.75 & & & \\
\hline Fat & day 30 & 4.31 & 4.37 & 041 & 0.71 & 0491 & $<0001$ & 0999 \\
\hline & day 60 & 4.17 & 4.25 & & 0.66 & 0.491 & $<0.001$ & 0.999 \\
\hline & day 90 & 4.80 & 4.88 & & 0.63 & & & \\
\hline & day 0 & 3.18 & 3.23 & & 0.67 & & & \\
\hline Protein & day 30 & 3.15 & 3.03 & 0256 & 0.31 & 0335 & 0000 & 0039 \\
\hline Protein & day 60 & 3.23 & 3.26 & 0.250 & 0.78 & 0.355 & 0.000 & 0.039 \\
\hline & day 90 & 3.27 & 3.59 & & 0.008 & & & \\
\hline & day 0 & 4.65 & 4.59 & & 0.38 & & & \\
\hline I actose & day 30 & 4.70 & 4.67 & 0151 & 0.55 & 0629 & 0517 & 0740 \\
\hline Lactose & day 60 & 4.66 & 4.65 & 0.151 & 0.94 & 0.029 & 0.511 & 0.140 \\
\hline & day 90 & 4.63 & 4.64 & & 0.56 & & & \\
\hline & day 0 & 15.5 & 16.6 & & 0.60 & & & \\
\hline Urea $\mathrm{mg}^{\circ} \mathrm{o}$ & day 30 & 15.8 & 15.8 & 475 & 0.97 & 577 & 0,045 & 0075 \\
\hline Urea mg\% & day 60 & 15.9 & 16.8 & 4.15 & 0.66 & $0.5 / 1$ & 0.045 & $0.9 / 5$ \\
\hline & day 90 & 18.9 & 19.7 & & 0.72 & & & \\
\hline
\end{tabular}

RMSE - root mean square error, $\mathrm{T} \times \mathrm{T}-$ time and treatment interaction

effect on lactation performance. In addition, Mogensen et al. (2010) reported that feeding high amounts $(21.3 \%$ of diet DM) of raw faba bean had no adverse effect on rumen environment and animal health.

Inclusion of extruded faba beans in dairy cow diet had no effect on milk composition (Table 6). However, cows fed extruded faba beans had lower milk protein concentrations $(P<0.008)$ in the last period of the experiment. This could be related to lower amount of amino acids absorbed in small intestine. Moreover, there was a significant treatment and time interaction for lower milk concentration for cows fed extruded beans. Similar to these findings, Puhakka et al. (2016) found that replacing the rapeseed meal in concentrate mixture with faba bean reduced the milk protein concentration. This leads to the conclusion that faba bean as the sole protein source in cow diets has a lower production potential compared to other common protein feeds.

In our study, indirect indicators of milk composition were used to evaluate the negative energy balance of dairy cows, as Reist et al. (2002) declared that ratios of milk components are more precise measures than the milk acetone in predicting energy balance in dairy cow post partum. In the present study, feeding extruded faba beans did not affect the overall milk fat and protein ratio, nor protein and lactose ratio, except for the protein and lactose ratio $(P<0.02)$ in the last period (Table 7). We assume that feeding relatively low amount of extruded faba beans, had an effect on milk component over the long-term feeding period. The mean 
Table 7. Effect of dietary treatments on milk traits and efficiency parameters per experimental periods

\begin{tabular}{|c|c|c|c|c|c|c|c|c|}
\hline \multirow{2}{*}{ Traits } & \multirow{2}{*}{ Days } & \multirow{2}{*}{ Control } & \multirow{2}{*}{ Experimental } & \multirow{2}{*}{ RMSE } & \multirow{2}{*}{$P$-value } & \multicolumn{3}{|c|}{$P$-value } \\
\hline & & & & & & treatment & time & $\mathrm{T} \times \mathrm{T}$ \\
\hline \multirow{5}{*}{$\begin{array}{l}\text { Energy corrected milk (ECM) } \\
\text { yield kg }\end{array}$} & day 0 & 34.0 & 33.2 & \multirow{4}{*}{4.326} & 0.70 & \multirow{4}{*}{0.288} & \multirow{4}{*}{0.048} & \multirow{4}{*}{0.570} \\
\hline & day 30 & 32.4 & 34.6 & & 0.28 & & & \\
\hline & day 60 & 29.2 & 31.8 & & 0.20 & & & \\
\hline & day 90 & 31.2 & 32.5 & & 0.50 & & & \\
\hline & overall & 31.7 & 33.0 & & 0.29 & & & \\
\hline \multirow{5}{*}{ Fat and protein ratio } & day 0 & 1.23 & 1.25 & \multirow{4}{*}{0.176} & 0.80 & \multirow{4}{*}{0.872} & \multirow{4}{*}{0.001} & \multirow{4}{*}{0.335} \\
\hline & day 30 & 1.45 & 1.37 & & 0.27 & & & \\
\hline & day 60 & 1.32 & 1.30 & & 0.84 & & & \\
\hline & day 90 & 1.38 & 1.48 & & 0.16 & & & \\
\hline & overall & 1.34 & 1.35 & & 0.87 & & & \\
\hline \multirow{5}{*}{ Protein and lactose ratio } & day 0 & 0.68 & 0.70 & \multirow{4}{*}{0.061} & 0.37 & \multirow{4}{*}{0.192} & \multirow{4}{*}{0.0007} & \multirow{4}{*}{0.1658} \\
\hline & day 30 & 0.67 & 0.65 & & 0.42 & & & \\
\hline & day 60 & 0.69 & 0.70 & & 0.68 & & & \\
\hline & day 90 & 0.71 & 0.77 & & 0.02 & & & \\
\hline & overall & 0.69 & 0.70 & & 0.19 & & & \\
\hline \multirow{5}{*}{ Feed efficiency } & day 0 & 1.48 & 1.44 & \multirow{4}{*}{0.158} & 0.58 & \multirow{4}{*}{0.531} & \multirow{4}{*}{$<0.0001$} & \multirow{4}{*}{0.369} \\
\hline & day 30 & 1.34 & 1.43 & & 0.27 & & & \\
\hline & day 60 & 1.23 & 1.32 & & 0.24 & & & \\
\hline & day 90 & 1.21 & 1.22 & & 0.96 & & & \\
\hline & overall & 1.32 & 1.35 & & 0.53 & & & \\
\hline \multirow{5}{*}{ Feed conversion ratio } & day 0 & 0.68 & 0.72 & \multirow{4}{*}{0.108} & 0.52 & & & \\
\hline & day 30 & 0.76 & 0.71 & & 0.34 & & & \\
\hline & day 60 & 0.83 & 0.77 & & 0.22 & 0.653 & $<0.0001$ & 0.328 \\
\hline & day 90 & 0.84 & 0.86 & & 0.72 & & & \\
\hline & overall & 0.78 & 0.76 & & 0.65 & & & \\
\hline & day 0 & 0.21 & 0.21 & & 0.73 & & & \\
\hline ECM yield / & day 30 & 0.20 & 0.21 & & 0.28 & & & \\
\hline net energy for lactation ( $\mathrm{NE}_{\mathrm{J}}$ ) & day 60 & 0.18 & 0.20 & 0.027 & 0.20 & 0.311 & 0.066 & 0.584 \\
\hline intake & day 90 & 0.19 & 0.20 & & 0.59 & & & \\
\hline & overall & 0.20 & 0.20 & & 0.31 & & & \\
\hline
\end{tabular}

RMSE - root mean square error, $\mathrm{T} \times \mathrm{T}-$ time and treatment interaction

milk fat and protein ratio was under 1.5 throughout the experiment, which indicates that the cows mobilised little or moderately their body reserves for milk production (Heuer et al., 1999).

Supplementation of extruded faba beans with concentrate mixture affected neither feed efficiency nor feed conversion ratios (Table 7). As the feed efficiency is mainly driven by dry matter intake (DMI), no difference between the groups was expected. These results corroborate the findings of Ramin et al. (2017) who reported no effect on feed efficiency $\left(\mathrm{kg} \mathrm{ECM} \mathrm{kg}^{-1}\right.$ DMI) when feeding untreated or heat-treated field beans to dairy cows. In addition, similar findings by Cherif et al. (2018) indicate feed efficiencies of 1.40 and 1.39 of cows fed either ground or rolled faba beans. In our study, the feed efficiency was in a range of 1.20 to 1.48 .

\section{Conclusions}

1. The extrusion process had a minor effect on the chemical composition of the faba beans; the crude protein and crude fat contents increased, while the neutral detergent fibre fraction decreased. Moreover, no significant effect on the $n-6: n-3$ ratio of fatty acids and the atherogenic and thrombogenic indices in beans were found.

2. The replacement of untreated beans with extruded beans in a dairy cow diet had no effect on feed intake or milk yield. Also, administration of extruded faba beans with concentrate mixture had no effect on other milk traits or efficiency parameters. These findings indicate that extrusion improves the composition of the treated beans, but the effect on lactation performance of a dairy cow is marginal.

3. It is suggested that extruded faba beans are a suitable partial replacement of protein source in dairy cow diets based on grass and maize silage.

\section{Acknowledgements}

The study was supported by the Ministry of Agriculture of the Republic of Lithuania project MT-177/PRM17-72. We would like to thank Dr. David Arney as a native English speaker for linguistic improvements to the final manuscript.

Received 04062019 Accepted 20092019

\section{References}

1. Aguilera J. F., Bustos M., Molina E. 1992. The degradability of legume seed meals in the rumen: effect of heat treatment. Animal Feed Science and Technology, 36: 101-112. https://doi.org/10.1016/0377-8401(92)90090-S

2. AOAC. 2000. Official methods of analysis ( $17^{\text {th }}$ ed.). Association of Official Analytical Chemists, USA.

3. Arija I., Centeno C., Viveros A., Brenes A., Marzo F., Illera J. C., Silvan G. 2006. Nutritional evaluation of raw and extruded kidney bean (Phaseolus vulgaris L. var. Pinto) in chicken diets. Poultry Science Journal, 85 (4): 635-644. https://doi.org/10.1093/ps/85.4.635

4. Björck I., Asp N. G. 1983. The effects of extrusion cooking on nutritional value - a literature review. Journal of Food Engineering, 2: 281-308. https://doi.org/10.1016/0260-8774(83)90016-X 
5. Cherif C., Hassanat F., Claveau S., Girard J., Gervais R., Benchaar C. 2018. Faba bean (Vicia faba) inclusion in dairy cow diets: effect on nutrient digestion, rumen fermentation, nitrogen utilization, methane production, and milk performance. Journal of Dairy Science, 101: 89168928. https://doi.org/10.3168/jds.2018-14890

6. Chrenkova M., Mlynekova Z., Formelova Z., Polacikova M., Rajsky M. 2017. Nutrition value of pea and effective degradability and digestibility of nutrients of untreated and extruded pea. Journal of Veterinary Science and Technology, 8 (6): 34.

7. Christopherson S. W., Glass R. L. 1969. Preparation of milk fat methyl esters by alcoholysis in an essential nonalcoholic solution. Journal of Dairy Science, 52: 1289-1290. https://doi.org/10.3168/jds.S0022-0302(69)86739-1

8. Commission regulation (EU) No 691/2013 of 19 July 2013 amending Regulation (EC) No 152/2009 as regards methods of sampling and analysis. http://eur-lex.europa.eu/ legal-content/EN/TXT/?uri=CELEX:32013R0691

9. Diaz D., Morlacchini M., Masoero F., Moschini M., Fusconi G., Piva G. 2006. Pea seeds (Pisum sativum), faba beans (Vicia faba var. minor) and lupin seeds (Lupinus albus var. multitalia) as protein sources in broiler diets: effect of extrusion on growth performance. Italian Journal of Animal Science, 5: 45-53. https://doi.org/10.4081/ijas.2006.43

10. Faithfull N. T. 2002. Methods in agricultural chemical analysis. A practical handbook. CABI Publishing, UK. https://doi.org/10.1079/9780851996080.0000

11. Focant M., Van Hoecke A., Vanbelle M. 1990. The effect of two heat treatments (steam flaking and extrusion) on the digestion of Pisum sativum in the stomachs of heifers. Animal Feed Science and Technology, 28: 303-313. https://doi.org/10.1016/0377-8401(90)90161-Z

12. Folch J., Lees M., Stanley G. H. S. 1957. A simple method for the isolation and purification of total lipides from animal tissues. The Journal of Biological Chemistry, 226: 497-509.

13. Goelema J. O., Spreeuwenberg M. A. M., Hof G., van der Poel A. F. B., Tamminga S. 1998. Effect of pressure toasting on the rumen degradability and intestinal digestibility of whole and broken peas, lupins and faba beans and a mixture of these feedstuffs. Animal Feed Science and Technology, 76: 35-50.

https://doi.org/10.1016/S0377-8401(98)00212-0

14. Goelema J. O., Smits A., Vaessen L. M., Wemmers A. 1999. Effects of pressure toasting, expander treatment and pelleting on in vitro and in situ parameters of protein and starch in a mixture of broken peas, lupins and faba beans. Animal Feed Science and Technology, 78: 109-126. https://doi.org/10.1016/S0377-8401(98)00266-1

15. Grela E. R., Günter K. D. 1995. Fatty acid composition and tocopherol content of some legume seeds. Animal Feed Science and Technology, 52: 325-331. https://doi.org/10.1016/0377-8401(94)00733-P

16. Hejdysz M., Kaczmarek S. A., Rutkowski A. 2015. Effect of extrusion cooking on the nutritional value of faba bean for broiler chickens. $20^{\text {th }}$ European Symposium on Poultry Nutrition. Prague, Czech Republic, p. 145.

17. Heuer C., Schukken Y. H., Dobbelaar P. 1999. Postpartum body condition score and results from the first test day milk as predictors of disease, fertility, yield, and culling in commercial dairy herds. Journal of Dairy Science, 82: 295304. https://doi.org/10.3168/jds.S0022-0302(99)75236-7

18. Huhtanen P., Hetta M., Swensson C. 2011. Evaluation of canola meal as a protein supplement for dairy cows: a review and a meta-analysis. Canadian Journal of Animal Science, 91: 529-543. https://doi.org/10.4141/cjas2011-029

19. Jeroch H., Drocher W., Simon O. 1999. Ernährung landwirtschaftlicher Nutztiere. Stuttgart, Germany, 544 p. (in German).

20. Kudlinskiene I., Gruzauskas R., Stanyte G., Klementaviciute J., Lionikiene J., Dauksiene A., Miezeliene A., Alencikiene G. 2018. Extruded field beans 'Fuego' (Vicia faba), its effects on dairy cow's performance, milk composition and sensory properties. Journal of Veterinary Science and Medical Diagnosis, 7 (4): 57.
21. Kudlinskienė I., Lionikienė J., Klementavičiūtė J., Stanytė G., Gružauskas R., Stankevičius R., Urbšienė D., Bliznikas S., Racevičiūtė-Stupelienè A., Ots M., Kass M. 2018. Effect of extruded field beans 'Fuego' (Vicia faba) on dairy cow's performance and milk sensory properties. Veterinarija ir zootechnika, 76 (98): 51-55.

22. Kushwah A., Rajawat P., Kushwah H. S. 2002. Nutritional evaluation of extruded faba bean (Vicia faba L.) as a protein supplement in cereals based diet in rats. The Indian Journal of Experimental Biology, 40 (1): 49-52.

23. Laudadio V., Ceci E., Tufarelli V. 2011. Productive traits and meat fatty acid profile of broiler chickens fed diets containing micronized fava beans (Vicia faba L. var. minor) as the main protein source. The Journal of Applied Poultry Research, 20: 12-20. https://doi.org/10.3382/japr.2010-00173

24. Makkar H. P. S., Becker K., Abel H., Pawelzik E. 1997. Nutrient contents, rumen protein degradability and antinutritional factors in some colour- and white-flowering cultivars of Vicia faba beans. The Journal of the Science of Food and Agriculture, 75: 511-520. https://doi. org/10.1002/(SICI)1097-0010(199712)75:4<511::AIDJSFA907>3.0.CO;2-M

25. Masoero F., Moschini M., Fusconi G., Piva G. 2006. Raw, extruded and expanded pea (Pisum sativum) in dairy cows diets. Italian Journal of Animal Science, 5 (3): 237-247. https://doi.org/10.4081/ijas.2006.237

26. Micek P., Kowalski Z. M., Kulig B., Kański J. 2015. Effect of variety and plant protection method on chemical composition and in vitro digestibility of faba bean (Vicia faba) seeds. Annals of Animal Science, 15: 143-154. https://doi.org/10.2478/aoas-2014-0080

27. Mogensen L., Vestergaard J. S., Fretté X., Lund P., Weisbjerg M. R., Kristensen T. 2010. Effect of toasting field beans and of grass-clover: maize silage ratio on milk production, milk composition and sensory quality of milk. Livestock Science, 128: 123-132. https://doi.org/10.1016/j.livsci.2009.11.011

28. Multari S., Stewart D., Russell W. R. 2015. Potential of fava bean as future protein supply to partially replace meat intake in the human diet. Comprehensive Reviews in Food Science and Food Safety, 14: 511-522. https://doi.org/10.1111/1541-4337.12146

29. Mutasim I., Khalil M., Salih A., Ali A. M. 2017. Study of fatty acid composition, physiochemical properties and thermal stability of broad beans (Vicia faba) seed oil. International Journal of Agriculture and Biology, 8 (4): $141-146$

30. NRC. 2001. Nutrient requirements of dairy cattle ( $7^{\text {th }} \mathrm{ed}$.). Washington, USA.

31. Puhakka L., Jaakkola S., Simpura I., Kokkonen T., Vanhatalo A. 2016. Effects of replacing rapeseed meal with faba bean at 2 concentrate crude protein levels on feed intake, nutrient digestion, and milk production in cows fed grass silage-based diets. Journal of Dairy Science, 99: 7993-8006. https://doi.org/10.3168/jds.2016-10925

32. Ramin M., Höjer A., Hetta M. 2017. The effects of legume seeds on the lactation performance of dairy cows fed grass silage-based diets. Agricultural and Food Science, 26: 129137. https://doi.org/10.23986/afsci.64417

33. Reist M., Erdin D., von Euw D., Tschuemperlin K., Leuenberger H., Chilliard Y., Hammon H. M., Morel C., Philipona C., Zbinden Y., Kuenzi N., Blum J. W. 2002. Estimation of energy balance at the individual and herd level using blood and milk traits in high-yielding dairy cows. Journal of Dairy Science, 85: 3314-3327. https://doi.org/10.3168/jds.S0022-0302(02)74420-2

34. Strauta L., Muizniece-Brasava S. 2016. The characteristics of extruded faba beans (Vicia faba L.). Rural Sustainability Research, 36 (331): 42-48. https://doi.org/10.1515/plua-2016-0013

35. TAR. 2015. Law of the Republic of Lithuania on Animal Care, Housing and Use, No. XI-2271 as well as complying with the amended Order of the State Food and Veterinary Service "On Approval for Requirements for Housing, Care and Use of Animals for Experimental and Other Scientific Research", No. B1-872. https://www.e-tar.lt/portal/lt/ legalAct/b0699db062c111e589fccd6fa118e11c 
36. Tufarelli V., Khan R. U., Laudadio V. 2012. Evaluating the suitability of field beans as a substitute for soybean meal in early-lactating dairy cow: production and metabolic responses. Animal Science Journal, 83: 136-140. https://doi.org/10.1111/j.1740-0929.2011.00934.x

37. Vadi M., Kaldmäe H., Kärt O., Ots M., Jürgenson A., Olt A. 2003. On the effect of processing temperature on rumen degradability of rapeseed cake proteins. Agraarteadus. The Journal of Agricultural Science, XIV (2): 119-124.

38. Vaga M., Hetta M., Huhtanen P. 2017. Effects of heat treatment on protein feeds evaluated in vitro by the method of estimating utilisable crude protein at the duodenum. Journal of Animal Physiology and Animal Nutrition, 101: 1259-1272.

https://doi.org/10.1111/jpn.12646
39. Vanhatalo A., Huhtanen P., Toivonen V., Varvikko T. 1999. Response of dairy cows fed grass silage diets to abomasal infusions of histidine alone or in combinations with methionine and lysine. Journal of Dairy Science, 82: $2674-2685$.

https://doi.org/10.3168/jds.S0022-0302(99)75524-4

ISSN 1392-3196 / e-ISSN 2335-8947

Zemdirbyste-Agriculture, vol. 107, No. 1 (2020), p. 87-94

DOI 10.13080/z-a.2020.107.012

\title{
Ekstrudavimo poveikis pašarinių pupų cheminei sudėčiai ir jomis šertų melžiamų karvių produktyvumui
}

\author{
I. Kudlinskienè $\dot{1}^{1}$, R. Gružauskas ${ }^{1}$, A. Daukšienè ${ }^{1}$, G. Dovidaitienè ${ }^{1}$, R. Želvytė ${ }^{1}$, \\ I. Monkevičienè ${ }^{1}$, E. Šlyžius ${ }^{1}$, D. Urbšienè ${ }^{2}$, A. Racevičiūtè-Stupelienè ${ }^{1}$, \\ M. Ots ${ }^{3}$, M. Kass ${ }^{3}$, H. Žilinskas ${ }^{1}$, R. Stankevičius \\ ${ }^{1}$ Lietuvos sveikatos mokslų universiteto Veterinarijos akademija \\ ${ }^{2}$ Lietuvos sveikatos mokslų universiteto Gyvulininkystės institutas \\ ${ }^{3}$ Estijos gyvybės mokslų universiteto Veterinarinès medicinos ir gyvūnų mokslų institutas
}

\section{Santrauka}

Tyrimo tikslas - nustatyti ekstrudavimo aukštoje temperatūroje ịtaką pašarinių pupų cheminei sudèčiai ir ịvertinti melžiamų karvių šèrimo pašarinėmis pupomis ịtaką jų produktyvumui. Pašarinės pupos buvo apdorotos vieno sraigto ekstruderiu $135-155^{\circ} \mathrm{C}$ temperatūroje. Buvo ištirta pašarinių pupų cheminè sudètis ir amino- bei riebalų rūgščių kompozicijos prieš ir po ekstrudavimą. Siekiant nustatyti pašarinių pupų ịtaką melžiamų karvių produktyvumui ir pieno suděčiai, atliktas melžiamų karvių šėrimo bandymas jų racione naudojant ekstruduotas ir neekstruduotas pašarines pupas. Tyrimo metu nustatyta, jog ekstrudavimas turejo nedidelę įtaką pašarinių pupu cheminei sudèčiai: žaliu baltymų ir žalių riebalų kiekis padidèjo, neutralaus detergento tirpale netirpios ląstelienos ir sausujų medžiagų kiekis sumažèjo, tačiau riebalų rūgščị n-6:n-3 santykiui, aterogeniškumo ir trombogeniškumo indeksams ekstrudavimas esminès ịtakos neturèjo. Neapdorotụ pašarinių pupų keitimas ekstruduotomis melžiamu karvių mityboje neturẻjo ịtakos pašarų suvartojimui ir produktyvumui. Taip pat ekstruduotu pašarinių pupų panaudojimas melžiamų karvių mityboje neturẻjo reikšmingos ịtakos pieno sudèties ir kokybės rodikliams.

Reikšminiai žodžiai: apdorojimas karščiu, melžiamos karvès, pieno sudètis, Vicia faba. 